\title{
OD/GA Sistemlerinde D/GA Makinesi Bekleme Noktasının Simülasyon ile Analizi: Rassal Depo İçi Atama Politikası Durumu
}

\author{
Analysis of S/R Machine Dwell Points in AS/RS using Simulation: Random Storage \\ Assignment Policy Case
}

Sema DEĞíRMEN-BEKTAŞ ${ }^{1} \mathbb{D}^{\mathbb{D}}$, Fatih ÇAVDUR $^{1}$

${ }^{1}$ Bursa Uludağ Üniversitesi, Endüstri Mühendisliği Bölümü, 06570, Bursa, Türkiye

$\ddot{O} z$

Otomatik Depolama ve Geri-Alma (OD/GA) sistemleri için kurulum aşamasında performans analizlerinin yapılması sistem tasarımının optimize edilmesi açısından önemlidir. Bununla birlikte, OD/GA sistemlerinin tasarımı gerçekleştirilirken, fiziksel tasarım parametrelerine ek olarak kontrol parametrelerinin de dikkate alınması gerekliliği karmaşık bir optimizasyon probleminin ortaya çıkmasına neden olmaktadır. Bu problemin ele alınmasında farklı parametre kombinasyonlarını içerecek şekilde esnek bir çözüm sistematiğinin geliştirilmesi önem kazanmaktadır. Bu çalışmada OD/GA sistemlerinin performans analizi için bir simülasyon modeli önerilmektedir. Önerilen model kullanılarak rassal depo içi atama politikası için farklı bekleme noktalarının (giriş, orta ve çıkış) dikkate alındığı senaryolar gerçekçi boyutlarda bir sistem için simüle edilerek sistem performansı ürünlerin sistemde geçirdikleri ortalama zaman, D/GA makinesinin ortalama seyahat süresi ve D/GA makinesi kullanım oranlarına göre incelenmektedir. Ele alınan örnekte, ürünlerin sistemde geçirdiği ortalama zaman ile D/GA makinesinin ortalama seyahat süresi açısından anlamlı farklılıkların oluşmadığı görülmektedir. Öte yandan, ele alınan örnek için D/GA makinesi bekleme noktası giriş konumundayken makine kullanım yüzdesinin daha düşük olduğu, dolayısıyla söz konusu konumlandırmanın daha iyi bir performansa sahip olduğu görülmektedir.

Anahtar Kelimeler: Otomatik Depolama ve Geri-Alma (OD/GA) sistemleri, bekleme noktası, rassal depo içi atama politikası, simülasyon, modelleme

\begin{abstract}
It is important to make a performance analysis of the system during installation of the Automated Storage and Retrieval Systems (AS/RS) for achieving an optimal design. Yet, it is quite a complex issue to deal simultaneously with physical design and control parameters in the design of AS/RS. It is thus necessary to maintain an adjustable design that contains variety of parameter combinations in solution of the problem. This study proposes a simulation model for performance analysis of AS/RS. By using the proposed model, the study examines system performance via simulating scenarios that considers a variety of dwell points (input, middle, and output) for random storage assignment policies for a realistically-sized system by considering the average time spent by the system performance products in the system, average travel time of the S/R machine and the percentage of the use of the $\mathrm{S} / \mathrm{R}$ machine. The findings obtained by the present example are that there is no considerable difference between the average travel time of the S/R machine and the average time spent by the products in the system. But, the percentage of the use of machine is lower when the $S / R$ machine is in the input position. It is thus concluded that the input point provides a better performance compared to other dwell points.

Keywords: Automated Storage and Retrieval Systems (AS/RS), dwell point, random storage assignment policy, simulation, modelling

\section{GİRiş}

Modern üretim ve dağıtım sistemlerinde ürün kullanılabilirliğini arttırırken işçilik maliyetini, gerekli kat alanını ve hata oranını düşüren yüksek stok seviyeli Otomatik Depolama ve Geri-Alma (OD/GA) sistemleri, 1950'lerden beri yaygın bir şekilde kullanılmaktadır. Bir OD/GA sistemi genel olarak raflar, Depolama ve Geri-Alma (D/GA) makineleri, koridorlar, giriş/çıkış noktaları ve bazı sistemlerde mevcut olan toplama pozisyonlarından oluşmaktadır. OD/GA sistemlerinin tasarımında dikkate alınan unsurlar genel olarak, sistemin fiziksel tasarımıyla ilişkili olan fiziksel tasarım ve sistem tarafından gerçekleştirilen operasyonlarla ilişkili olan kontrol parametreleri olmak üzere ikiye ayrılabilir. Fiziksel tasarım ve kontrol parametrelerinin birbirleri ile olan ilişkileri ve bu unsurlara ait bazı örnekler Şekil 1'de yer almaktadır.
\end{abstract}

Fiziksel tasarım parametreleri genel olarak sistemin görünümünü belirleyen sistem seçimi ve sistem yapılandırmalarını içeren sistem konfigürasyonundan meydana gelmektedir. Sistem tarafından gerçekleştirilen operasyonlar ile ilgili olan kontrol parametreleri ise genel olarak depo içi atama, gruplama, sıralama ve bekleme noktası değişkenlerinden oluşmaktadır. Kısaca özetlemek gerekirse, depo içi atama politikaları, depolama raflarına 
ürünlerin depolanması için kullanılan yöntemlerden (örneğin, atanmış, rassal, sınıf-tabanlı depo içi atama politikaları vs.) oluşmaktadır. Gruplama, bir dizi siparişin olduğu durumlarda siparişlerin birleştirilerek D/GA makinesi tarafından tek turda toplanması için belirlenen kurallardan oluşurken; sıralama, ürünlerin geri-alınma sıralarının teslim zamanlarının dikkate alınarak belirlenmesini içeren kurallardır. Bekleme noktası ise D/GA makinesi hiçbir işlem gerçekleştirmiyorken beklediği konuma karşılık gelmektedir. D/GA makinesinin bir ürünü depolamak veya geri-almak için geçirdiği sürenin (travel time) değerlendirilmesi de optimal bir tasarım için gereklidir ve bu süre, farklı fiziksel tasarım ve kontrol parametrelerine göre değişebilmektedir [2]. Kontrol parametrelerinden olan bekleme noktasının seçimi de ürünlerin depolanması ve geri-alınması için hem ürünlerin sistemde geçirdikleri süreyi hem de D/GA makinesinin bir sonraki ürün talebini gerçekleştirmek için geçireceği süreyi etkilemektedir. İyi bir bekleme noktasının seçimi ile toplam işlem tamamlanma süreleri kısaltılabilmekte ve böylece toplam işlem süresi azaltılabilmektedir [3]. Dolayısıyla, bekleme noktası probleminin literatürde çok çalışıldığını [4] hem analitik hem de simülasyon modellerinin problemin çözümü için kullanıldığını görmekteyiz.

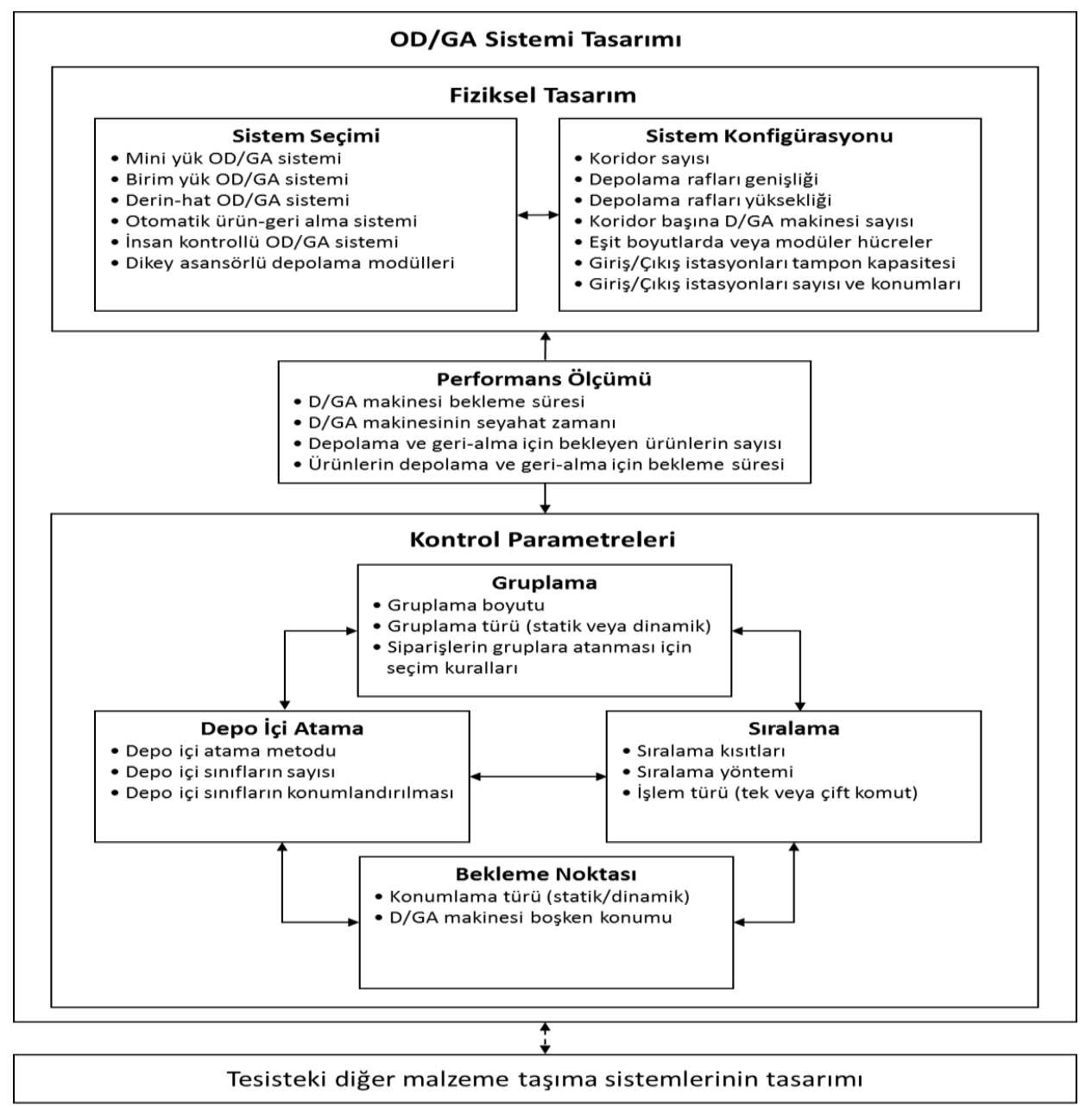

Şekil 1. OD/GA sistemi tasarımı (Roodbergen ve Vis [1] tarafından yapılan çalışmadan değiştirilerek alınmıştır)

Genel bir ifade ile OD/GA sistemi, malzemeleri belirli bir otomasyon derecesinde hassas, doğru ve hızlı bir şekilde işleyen, depolayan ve geri-alan ekipman ve kontrollerin birleşimidir. OD/GA sistemlerinde amaç, bilgisayar kontrolünde hızlı yük erişimi ile yüksek yoğunlukta depolama sağlamaktır. Bu sistemler, daha hızlı depolama ve ürün alma, depolama alanını verimli kullanma, yüksek güvenilirlik ve ürün hasarlarındaki azalma gibi avantajlara sahipken; yüksek başlangıç yatırımları ve depo tasarımının değiștirilmesinin zorluğu gibi ekonomik faktörleri içeren dezavantajlara da sahiptir. İmalat, depolama ve dağıtım merkezlerinde kullanılan OD/GA sistemlerinin hem verimli çalışması hem de ürünlerin depolanması ve geri-alınması için hızlı tepki verecek şekilde tasarlanması beklenmektedir. Aynı zamanda depo tasarımı, hem araştırmacılar hem de endüstriyel uygulayıcılar için çok önemli bir sorun olarak bilinmektedir. Depolama sistemlerine ilişkin verimlilik ve lojistik maliyetleri, tasarım kararlarından büyük ölçüde etkilenmektedir. $\mathrm{Bu}$ kararlar, sistemin uzun vadeli genel yap1 tasarımından günlük operasyonel kontrolüne kadar geniş bir dizi konu içermektedir [5]. Dolayısıyla, yüksek verimli ve yüksek esneklikte otomatik depolama sistemleri geliştirilirken, yüksek yatırım maliyetleri nedeniyle sistemlerin performans 
tahminleri pratikte ve teorik açıdan önem kazanmaktadır.

OD/GA sistemlerinde fiziksel tasarım, kontrol parametreleri ve müşterilerden gelen istek ve kısıtların yanında sistem ile ilgili belirsizliklerin de olması (örneğin; talep dalgalanmaları vb.) sistem tasarımını etkilemektedir. $\mathrm{Bu}$ doğrultuda, OD/GA sisteminin planlanması, tasarımı, inşası, analizi ve yönetimi karmaşık bir problem haline gelmektedir. $\mathrm{Bu}$ tür karmaşık bir optimizasyon probleminin çözümü için genel olarak söz konusu problemi daha dar kapsamda ve çeşitli varsayımlar altında ele almak amacıyla analitik modellerin kullanılması uygun görülmektedir. Ancak sistem ile ilgili belirsizlik içeren koşulların ele alınması, hem tasarım hem kontrol parametrelerinin bütünleşik olarak dikkate alındığı kapsamlı bir formülasyonun geliştirilmesinin zorluğu gibi nedenlere bağlı olarak, söz konusu problemin analitik modeller ile incelenmesini zorlaştırabilmektedir. Böyle karmaşık bir problemin incelenmesinde analitik modellerin yanında, sistemin performans tahmini, analizi ve çeşitli kurgularının/senaryolarının incelenebilmesi için daha esnek bir yapı sağlayan simülasyon modelleri de sıklıkla kullanılmaktadır.

$\mathrm{Bu}$ çalışmada, OD/GA sistemlerinin simülasyon ile modellenmesi ele alınmaktadır. Çalışma kapsamında, simülasyon modelinin alt yapısının oluşturulması için bir yaklaşım önerilmiş olup ilgili yaklaşımın örneklendirilmesi amaciyla örnek bir depo oluşturulmuştur. Ele alınan örnekte, rassal depo içi atama politikası ile farklı bekleme noktaları kombinasyonları ayrı ayrı dikkate alınmış olup ilgili politikalar sistem performansı açısından karşılaştırılarak hangi bekleme noktasının rassal depo içi atama politikası altında daha iyi sonuç verdiği analiz edilmiştir.

\section{KAYNAK ARAŞTIRMASI}

OD/GA sistemlerinin farklı fiziksel tasarım ve/veya çeşitli kontrol parametreleri altında hem analitik modeller ile hem de simülasyon modelleri ile incelenmesi konusu literatürde de geniş yer kaplamaktadır. Literatürde birçok çalışmanın yer alması literatür tarama çalışmalarını da beraberinde getirmiştir. Roodbergen ve Vis [1], OD/GA sistemlerinin son 30 yıldaki literatürüne genel bir bakış sunmuşlardır. Gagliardi vd. [6], OD/GA sistemleri ile ilgili yapılan çalışmalarda ele alınan özel araştırma soruları ile ilgili sistemleri değerlendirmek amacıyla tasarlanmış ve çeşitli modeller için kullanılan varsayımlara odaklanmışlardır. Vasili vd. [7] tarafindan yapılan çalışmada ise son 40 yıldaki OD/GA sistemleri literatürüne genel bir bakış sunulmaktadır.

Çalışmanın 'Giriş' bölümünde de belirtildiği gibi OD/GA sistemlerinin performans analizi için birçok analitik model literatürde yer almaktadır. Ancak, hem müşterilerden gelen kisitlar ve belirsizliklerden kaynaklanan stokastik koşulların dikkate alınması hem de OD/GA sistemlerinin etkileşimde olduğu diğer sistemleri etkilemesi, fiziksel tasarım ve kontrol parametrelerinin doğru bir şekilde seçimi için bütünleşik olarak büyük bir formülasyonun geliştirilmesi gerekliliğini doğurmaktadır. Dolayısıyla, OD/GA sistemlerinin analizi ve sistem ile ilgili çeşitli kurguların/senaryoların incelenebilmesi için analitik modellerin yanında veya analitik modeller ile birlikte simülasyon modellerinin de sıklıkla kullanıldığını görmekteyiz. Örneğin, Potrc vd. [8], tekli ve çoklumekik OD/GA sistemlerinin analizi için hem analitik modeller hem de simülasyon modeli kullanmışlardır. Yazarlar, D/GA makinesinin hızının değişken olduğu durumlarda tek ve çift komut çevrimleri için kullanılan temel analitik modelleri, dörtlü komut çevrimi (bir çevrimde iki depolama ve iki geri-alma) ve altılı komut çevrimi (bir çevrimde üç depolama ve üç geri-alma) için genişletmişlerdir. Ancak, analitik modellerin yeterli doğruluğu sağlayamadığı, sadece mevcut duruma yaklaştığı sonucuna vararak, simülasyon modeli geliştirmiş ve çalışma kapsamında önerilen depolama stratejisinin performansını değerlendirmişlerdir. Eldemir vd. [9], birim-yük OD/GA sistemlerinde çift komut ile tek komut çevrimlerinin oranını tahmin etmek için alternatif analitik yaklaşımları kullanmış olup, ilgili yaklaşımlarda yer alan modelleri simülasyon ile karşılaştırmışlardır. Lerher vd. [10] tarafından yapılan çalışmada, çok-koridorlu OD/GA sistemleri için analitik seyahat süresi modelleri önerilmiş ve önerilen modellerin performanslarını karşılaştırmak için simülasyon modeli geliştirilmiştir. Guo ve Liu [11], tekli ve ikili-mekik OD/GA sistemlerinin maliyet ve performanslarını karşılaştırmak için simülasyon kullanmışlardır. Yan ve Lee [12], simülasyon modelini, bir OD/GA sisteminde maliyeti tahmin etmek ve verimliliği arttırmak için kullanmışlardır. Lerher vd. [13] tarafından yapılan çalışmada, çift derinlikli, birimyük OD/GA sistemlerinde çevrim zamanlarının hesaplanması için sundukları yeni analitik seyahat zamanı modellerinin performanslarını simülasyon modeli geliştirerek karşılaştırmışlardır. Tang vd. [14], bir üretim işletmesinde kullanılacak olan OD/GA sistemi için genel süreci ve ayrıntılı adımları analiz etmiş ve sistemin dar boğazlarını tanımlamak amacıyla simülasyon kullanmışlardır. Gagliardi vd. [15] tarafından yapılan çalışmada, birim-yük OD/GA sistemleri için fiziksel tasarım kararlarını operasyonel kararlardan ayırarak, OD/GA sistem dinamiklerinin daha iyi anlaşılmasını ve modeldeki esnekliği arttırmayı mümkün kılan ve birçok ilginç senaryonun temsil edilmesini sağlayan nesne tabanlı simülasyon modeli (object oriented simulation model) sunulmuştur. Bahrami vd. [16] tarafindan yapılan çalışmada, farklı fiziksel tasarım ve kontrol politikalarını analiz etmek ve sonuçları karşılaştırmak için koridor-sonu OD/GA sistemi simülasyonu sunulmuştur. Fan vd. [17] ise çok-derinlikli OD/GA sisteminde $\mathrm{D} / \mathrm{GA}$ makinesinin seyahat süresini simülasyon yöntemlerine dayalı olarak araştırmışlardır. 
OD/GA sistemleri hem yüksek maliyetli olması hem de etkileşimde bulunduğu diğer sistemlerin performansını da etkilemesi sistem tasarımını daha önemli bir hale getirdiği daha önce belirtilmişti. Fiziksel tasarım ve kontrol parametrelerinin seçimini içeren sistem tasarımının doğru bir şekilde belirlenmesi, sistem kurucular tarafindan istenmektedir. D/GA makinesi bekleme noktası seçiminin de sistem performansını etkilediği bilinmektedir. Öte yandan, bu parametrenin diğer parametrelerle (örneğin, depo içi atama politikası) olan ilişkisinin sistem performansı üzerinde olan etkisi de literatürde incelenen konular arasındadır. D/GA makinesi bekleme noktası politikalarının sistem performansı üzerindeki etkisinin incelenmesi için de yine analitik modellerin yanında simülasyon modelleri de kullanılmaktadır. Örneğin, Van Den Berg ve Gademann [18], çeşitli kontrol politikaları altında depo içi atama politikalarını simülasyon ile incelemişlerdir. Meller ve Mungwattana [19], OD/GA sisteminde en iyi bekleme noktası stratejisini belirleme amaçlayarak sektörde kullanılan bekleme noktası seçim politikalarından literatürde önerilen daha gelişmiş politikalara kadar değişen çeşitli bekleme noktası stratejilerini simülasyon ile araştırmışlardır. Manzini vd. [20], OD/GA sistemlerinde sınıf-tabanlı depo içi atama stratejisi ile ürün-toplayıcı depolama sisteminin (product-to-picker storage system) çoklu-parametrik (multi-parametric) dinamik modelini sunmuşlardır. Alternatif tasarım ve işlem konfigürasyonlarının beklenen sistem performansı üzerindeki etkisini ölçmek ve sistemin tepkisine (response of the system) etki eden faktörlerin en kritiklerini ve bunların kombinasyonlarını tanımlamak için binlerce eğer-ise (what-if) senaryolarını simüle etmişlerdir. Zhou ve Mao [21] yaptıkları çalışmada, depo içi atama için matematiksel model oluşturup çözdükten sonra simülasyon ile depo içi atama tasarımını ve analizini gerçekleştirmişlerdir. Gagliardi vd. [22], bir gida endüstrisindeki OD/GA sisteminin özelliklerini doğru bir şekilde belirlemek için tasarlanmış olan ayrık-olay simülatörü sunmuş ve farklı depo içi atama politikaları altında sistemin performansını karşılaştırmak için çeşitli senaryolar oluşturmuşlardır. Meneghetti ve Monti [23], OD/GA sistemine enerji odaklı bakmış ve $\mathrm{OD} / \mathrm{GA}$ sistemi rafındaki her hücreyi D/GA makinesinin kendisine ulaşması için tükettiği enerjiyle ilişkilendirerek depolama ve geri-alma politikalarını enerji performansları açısından değerlendirmişlerdir. Yazarlar, bekleme noktası politikalarını da bu perspektiften incelemiş olup, depo içi atamalar arasındaki enerji tüketimini karşılaştırmak için gerialma işlemlerinin simülasyonlarını gerçekleştirmişlerdir. Regattieri vd. [4], farklı kurallar arasında bekleme noktası politikası için en iyi çözümü bulmak ve böylece depolama/istifleme makinelerinin (stacker cranes) seyahat süresini ve mesafesini en aza indirgemeyi amaçlayan bir model geliştirmişlerdir. Yazarlar, önerilen modelin bilgisayar simülasyonlarıyla doğrulanması için de bir yazılım platformu (software platform) geliştirmişlerdir. Schenone vd. [24] yaptıkları çalışmada, farklı kullanım alanlarındaki OD/GA sistemlerini dikkate alarak, sınıftabanlı depo içi atama politikası altında bir OD/GA sisteminin seyahat süresini hesaplamak için simülasyon yaklaşımına dayanan uygun bir metodoloji geliştirmeyi amaçlamışlardır.

Bu çalışmada, literatürde yer alan çalışmalardan farklı olarak OD/GA sistemlerinin simülasyon ile modellenmesi amacıyla bir yaklaşım önerilmektedir. Yapılan literatür taramalarında böyle bir çalışmaya rastlanmamış olup, benzer çalışmalarda ise mevcut paket programların kullanıldığ 1 ve sistemin bu paket programlar ile simüle edildiği görülmektedir.

\section{METODOLOJİ}

Bu çalışmada, OD/GA sistemi simülasyonu için bir yaklaşım önerilmektedir. Önerilen yaklaşımda, ayrıkolay simülasyon modelinin oluşturulması için kullanılan unsurlar bu bölümde özetlenmiştir. Simülasyon modeli oluşturulurken kullanılan $i$ ve $j$ indisleri, sırasıyla, koridor ve ilgili koridora depolamak ve geri-almak için gönderilen ürün grubunu ifade etmektedir. Burada indis sinırları $i=1 \ldots n$ ve $j=$ $1 \ldots m_{i}$ olarak tanımlanmakta olup; $n$ toplam koridor sayısına; $m_{i}$ ise $i$. koridora gönderilen toplam ürün grubu sayısına karşılık gelmektedir.

Simülasyon modelinde kullanılan varlıklar, en genel şekliyle Tablo 1'de yer aldığ 1 gibi sanal varlıklar ve diğer varlıklar olarak ikiye ayrılabilir. Burada sanal varlıklar, problem içinde standart bileşenlerle ele alınamayan karmaşıklıktaki unsurların modellenmesi amacıyla, simülasyonun başlatılması ve ürün gruplarının depolanacakları koridorlara gönderilmesi için kullanılan çeşitli kukla varlıklar şeklinde tanımlanmakta; diğer varlıklar ise hücrelerde depolanacak olan ürün gruplarını ifade etmektedir.

\begin{tabular}{|c|c|c|}
\hline Varlık Tanımı & & Varlık \\
\hline Sanal Varlıklar & $:$ & $\begin{array}{l}\text { Storage_Demand } \\
\text { Storage_Demand_ } i\end{array}$ \\
\hline Diğer Varlıklar & : & Product_Groups_ij \\
\hline
\end{tabular}

Simülasyon modelinde kullanılan lokasyonlar, depolama, geri-alma veya başka bir faaliyet (taşıma, bekleme) için varlıkların yönlendirildiği konumlara karşılık gelmektedir. Modelde yer alan lokasyonlar, giriş ve çıkış noktaları, koridorlara ait kuyruklar ve konveyörler ile birlikte, OD/GA sisteminde ürünlerin depolanması ve geri-alınması için kullanılan ve raflarda yer alan hücrelerden oluşmakta olup Tablo 2'deki gibi özetlenebilir. Burada da varlıklarda yer alan sanal varlık tanımlarına benzer şekilde, simülasyonu başlatmak için sanal varlığının sisteme giriş yaptığ sanal bir lokasyon kullanılmıştır. Storage_Demand sanal varlığı, sanal lokasyondan sonra, öncelikle Storage_Demand_ $i$ sanal varlığı olarak, daha sonra ise Storage_Demand_i sanal varlığ 
Product_Groups_ij ürün grupları olarak giriş noktasına gönderilmektedir. Ürün gruplarının, $i$. koridordaki hücrelere depolanmak üzere giriş, gerialınan ürünlerin ise çıkış yapabilmesi amacıyla kullanılan koridor kuyruklarına ürünler gönderilmeden önce, ilgili kuyruğa ait konveyörler bulunmaktadır. $i$. koridordaki hücrelere depolanmak için gelen ürünler ile hücrelerden geri-alınan ürünler, kuyruklardaki olası doluluğa karşı oluşabilecek darboğazları engellemek amaciyla tampon bölgelerde beklemektedirler. Giriş lokasyonundan sonra konveyöre, sonra ilgili kuyruğa ve tampon bölgeye gelen ürün grupları, depo içi atama politikaları dikkate alınarak hücrelere depolanmakta ve daha sonra geri-alma talebi olan ürün grupları alınarak çıkış noktasından sistemden çıkarılmaktadır.

Çalışmanın "Giriş” bölümünde belirtildiği gibi sistemde yer alan koridorlar, raflar arasındaki boșlukları ifade etmektedir. Dolayısıyla, iki raf bölümünden oluşan bir koridorda bulunan D/GA makinesi, her iki raf bölümünde yer alan hücrelere hizmet vermektedir. Hücreler tanımlanırken, hücrenin hangi koridorda, hangi raf bölümünde olduğu ve ilgili raf bölümü için hangi koordinatta yer aldığı dikkate alınmıştır. Bu doğrultuda, Loc_isxxyy olarak ifade edilen hücre lokasyonunda $i$, daha önce belirtildiği gibi koridoru; $s$, ilgili koridorda karşılıklı olarak yer alan raf bölümlerini $(s=1,2) ; x x$, hücrenin bulunduğu lokasyonun $x$ koordinatını; $y y$ ise hücrenin bulunduğu lokasyonun $y$ koordinatını ifade etmektedir. Lokasyonlara ait örnek bir gösterim Şekil 2'de yer almaktadır.

Tablo 2. Lokasyonlar

\begin{tabular}{lll}
\hline Lokasyon Tanımı & Lokasyon \\
\hline Sanal Lokasyon & $:$ & Dummy_Location \\
\hline Giriş ve Çıkış Noktaları & $:$ & $\begin{array}{l}\text { Input } \\
\text { Output }\end{array}$ \\
\hline Konveyörler & $:$ & $\begin{array}{l}\text { Input_Conveyor } \\
\text { Input_Conveyor_i } i \\
\text { Output_Conveyor_i } \\
\text { Output_Conveyor }\end{array}$ \\
\hline Kuyruklar & $:$ & $\begin{array}{l}\text { Input_Que_i } \\
\text { Output_Que_i }\end{array}$ \\
\hline Tampon Bölgeleri & $:$ & $\begin{array}{l}\text { Input_Buffer_i } \\
\text { Output_Buffer_i } i\end{array}$ \\
\hline Hücreler & $:$ & Loc_isxxyy \\
\hline
\end{tabular}

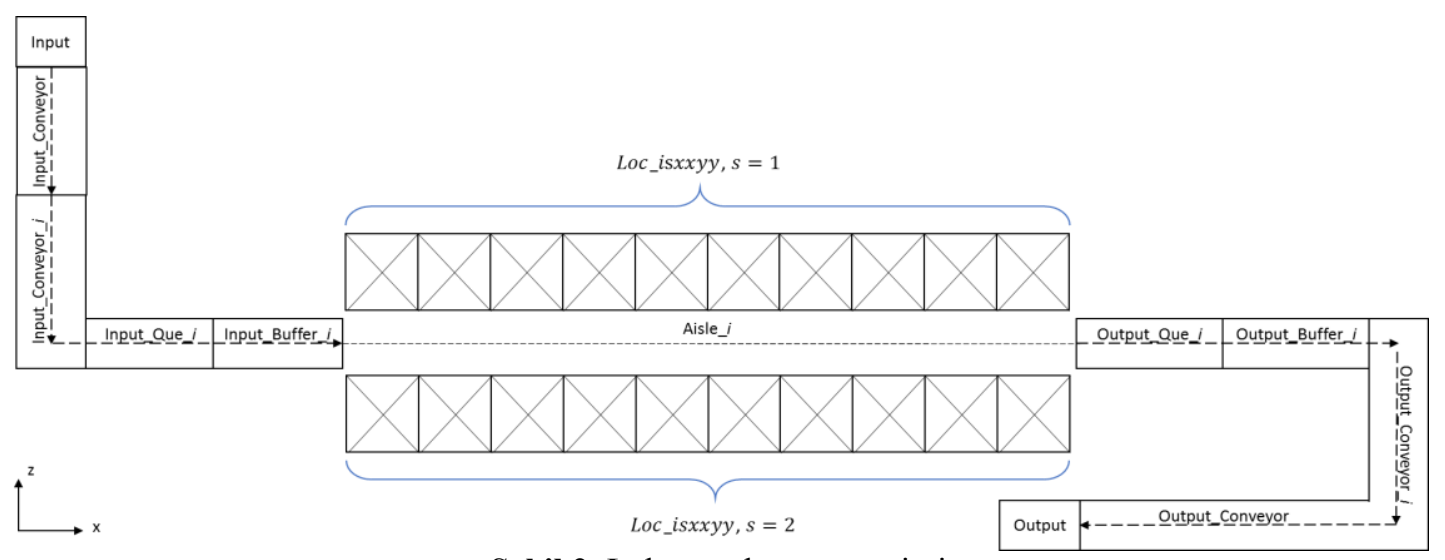

Şekil 2. Lokasyonların gösterimi

Simülasyon modelinde kullanılan değişken ve nitelikler tanımları ile birlikte Tablo 3 ve 4 'te yer almaktadır.

Tablo 3. Değişkenler

\begin{tabular}{|c|c|c|}
\hline Değişken Tanımı & & Değişken \\
\hline $\begin{array}{l}\text { Giren/Çıkan Ürün } \\
\text { Sayısı }\end{array}$ & $:$ & $\begin{array}{l}\text { Var_Input_Product_Groups_ij } \\
\text { Var_Output_Product_Groups_ij }\end{array}$ \\
\hline $\begin{array}{l}\text { Giren/Çıkan Toplam } \\
\text { Ürün Sayısı }\end{array}$ & $:$ & $\begin{array}{l}\text { Var_InputQue_i } \\
\text { Var_OutputQue_i }\end{array}$ \\
\hline Isınma Periyodu & $:$ & $\begin{array}{l}V a r_{-} W T \\
V a r_{-} W T C_{-} i j \\
V a r_{-} W T C_{-} i c_{i} \\
V a r_{-} W T_{-} i j \\
V a r_{-} W T_{-} i c_{i}\end{array}$ \\
\hline Depolama Süresi & $:$ & $\begin{array}{l}V a r_{-} S T \\
V a r_{-} S T C_{-} i j \\
V a r_{-} S T C_{-} i c_{i} \\
V a r_{2} S T_{-} i j \\
V a r_{-} S T_{-} i c_{i} \\
\end{array}$ \\
\hline
\end{tabular}

Tablo 4. Nitelikler

\begin{tabular}{|c|c|c|}
\hline Nitelik Tanımı & & Nitelik \\
\hline $\begin{array}{l}\text { Olasılık Dağılımları } \\
\text { Ataması }\end{array}$ & : & $\begin{array}{l}A t t_{-} S A \\
A t t_{-} S P T_{-} i\end{array}$ \\
\hline Isınma Periyodu & : & $A t t_{-} W T$ \\
\hline Depolama Süresi & : & $A t t \_S T$ \\
\hline
\end{tabular}

Çalışma kapsamında geliştirilen simülasyon modelinde dikkate alınması gereken bir diğer unsur da simüle edilen sistemin başlangıç koşullarıdır. Bu çalışmada dikkate alınan sistemin kararlı durum koşullarını model yansıtabilmek amacıyla, sistemin başlangıçta belirli bir miktarda doluluğa sahip olduğu varsayılmıştır. Söz konusu başlangıç koşullarının oluşturulabilmesi için depoda geri-alma talebi olmadan belli bir süre boyunca sadece depolama işleminin gerçekleştirilmesi şeklinde bir modelleme yaklaşımı öngörülmüştür. Ürün 
çeşitliliği ve depolama politikalarıla birlikte ele alındığında isınma periyodunun belirlenmesi bu yaklaşımın kapsamlı olarak tasarlanmasını gerektirmekte olup, uygulanan yaklaşımın detayları izleyen paragrafta sunulmuştur.

Başlangıç koşullarının oluşturulmasını sağlamak amacıyla farklı koridorlarda farklı ürün gruplarının çeşitli depo içi atama politikaları altında depolanma olasılıkların da dikkate alarak 1sınma periyodunun (warm-up time) belirlenmesi önerilmektedir. Isınma periyodunu oluşturmak amaciyla Tablo 3 ve 4'te yer alan ve isınma periyodu ile ilgili olan değişken ve niteliklerden yararlanılmıştır. $\mathrm{Bu}$ amaçla, öncelikli olarak farklı koridorlardaki hücrelere depolanmak üzere gelen ürün gruplarına ait ortak/genel bir çarpan olan Var_WT değiş̧eni tanımlanmıştır. Ürün gruplarının depolama politikalarına ve talep edilme olasılıklarına bağlı olarak depoya geliş sıklıkları farklılık gösterebilmektedir. Dolayısıyla, ürün gruplarının geri-alma talepleri olmadan (başlangıç durumunda) belirli bir süre ilgili hücrelere depolanması için ısınma periyotlarının da ürün gruplarına ya da ürün sınıflarına göre farkl1lık göstermesi gerekmektedir. Aksi durumda, daha sık frekanslarla depoya gelen ürün grupları, başlangıç durumunda ısınma periyodu boyunca beklerken darboğazlara neden olabilir. Bu durumun giderilmesi için $i$. koridordaki hücrelere depolanan $j$. ürün grubuna ait 1sınma periyodu katsayıları Var_WTC_ij değiş̧keni ile tanımlanmıştır. $\mathrm{Bu}$ değişkenin $\left(V a r_{-} W T C_{-} i j\right)$, genel isınma periyodu $\left(V a r_{-} W T\right)$ ile çarpılmasıyla da $i$. koridordaki hücrelere depolanan $j$. ürün grubuna ait $V a r_{-} W T_{-} i j$ değişkeni ile tanımlanan ısınma periyodu belirlenmiş olmaktadır. Diğer bir yandan, sınıf-tabanlı depo içi atama politikasının da depoda kullanılması söz konusu olabilir. Dolayısıyla burada, her bir ürün grubu yerine farklı sınıflara ait ürün grupları için farklı 1sınma periyotlarının belirlenmesi gerekmektedir. Daha önce de belirtildiği gibi aksi durumda, talep edilme olasıllı̆g yüksek olan sınıflar ile talep edilme olasıllı̆̆ düssük olan sınıfların depolanacağı hücre sayıları ve depoya geliş sıklıkları farklılık göstereceğinden, ürünlerin aynı ısınma periyodu süresince beklemeleri sistemde darboğazlara neden olabilir. $\mathrm{Bu}$ sorunu gidermek amacıyla, eğer varsa, sınıf-tabanlı depo içi atama politikası altında depolanan ürün grupları için de $V a r_{-} W T C_{-} i c_{i}$ değişkeni katsayı oluşturmak üzere tanımlanmıştır. Bu katsayı değişkeninin, genel ısınma periyodu katsayısıyla (Var_WT) çarpılması ile de $V a r_{-} W T_{-} i c_{i}$ değişkeni ile tanımlanan sınıf-tabanlı depo içi atama politikası altında depolanan ürün gruplarına ait sınıfların, ısınma periyotları belirlenmiş olmaktadır. Burada, $c_{i}$ değeri, $i$. koridorda sınıf-tabanlı depo içi atama politikası altında depolanan ürün gruplarının sinıf sayısını temsil etmekte ve sinıf sayısına göre değişkenlik göstermektedir. Örneğin, birinci koridorda $(i=1)$, üç farklı sınıf yer alıyorsa $c_{1}=3$ olmaktadır. Son olarak, belirlenen isınma periyodu değişkenleri $\left(V a r_{-} W T_{-} i j\right.$ ve Var_WT_ic $c_{i}$ ), $A t t \_W T$ niteliğine eşitlenerek ilgili ürün grupları için başlangıç bekleme süreleri oluşturulmuş olmaktadır.

Isınma periyodunun belirlenmesinden sonra ürün gruplarının depolama sürelerinin de oluşturulması gerekmektedir. Başlangıç durumunda isınma periyodu kadar bekleyen ürün grupları, depolama süreleri boyunca da bekledikten sonra geri-alma sürecine geçilmektedir. Depolama süresi, ürün grupları sisteme giriş yapıp ilgili koridordaki hücreye depolandıktan sonra başlamaktadır. Depolama süreleri belirlenirken yine isınma periyoduna benzer bir süreç izlenmektedir. Genel bir depolama süresi Var_ST değişkeni ile belirlendikten sonra, bu değişken yine depo içi atama politikasına göre $V a r_{-} S T C_{-} i j$ veya $V a r_{-} S T C_{-} i c_{i}$ (sınıftabanlı ise) değişkeni ile tutulan katsayılar ile çarpılarak Var_ST_ij veya $V a r_{-} S T_{-} i c_{i}$ değişkenleri elde edilmektedir. Elde edilen değişkenler, Att_ST niteliği ile tutularak her ürün grubuna veya sınıfa ait depolama süreleri oluşturulmaktadır.

Simülasyon modelinin oluşturulması için kullanılan model bileşenleri dışında bir diğer unsur da D/GA makinesinin çevrim sürecidir. Önerilen yaklaşımda Şekil 3'te verildiği gibi üç çevrim düşünülmektedir. Depolama çevriminde (Şekil 3-(a)), bekleme noktasında (BN) bekleyen D/GA makinesi, giriş noktasından (GN) depolanacak ürünü alıp depolama noktasına (DN) götürdükten sonra bekleme noktasına geri dönmektedir. Geri-alma çevriminde (Şekil 3-(b)), yine bekleme noktasinda bekleyen D/GA makinesi, geri-alma noktasından (GAN) ürünü alıp çıkış noktasına (ÇN) götürdükten sonra bekleme noktasına geri dönmektedir. Şekil 3-(c) ile gösterildiği gibi ikili çevrimde ise hem depolama hem de geri-alma taleplerinin aynı zaman diliminde var olduğu düşünülmektedir. İkili çevrimde, bekleme noktasında bekleyen D/GA makinesi, depolama talebini gerçekleştirdikten sonra geri-alma konumundan gerialınacak ürünü almaktadır. Alınan ürünün çıkış noktasına birakılmasından sonra yine bekleme noktasına geri dönmektedir. Burada belirlenen bekleme noktası, giriş veya çıkış noktası olabileceği gibi başka bir lokasyon (örneğin, orta nokta) olarak da belirlenebilir. 


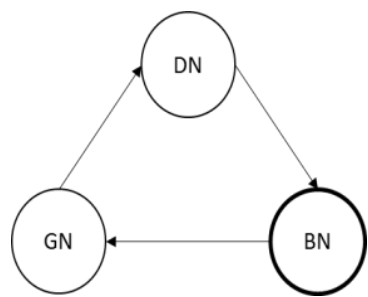

(a)

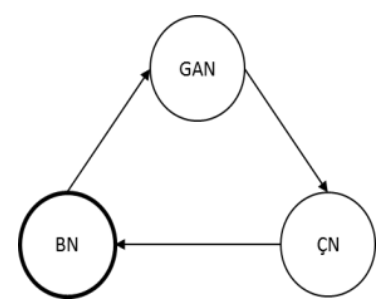

(b)

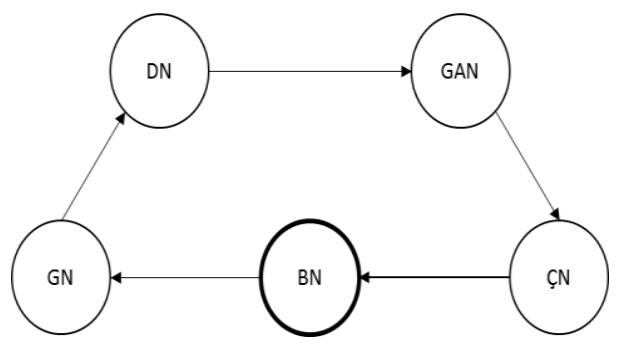

(c)

Şekil 3. D/GA makinesi bekleme noktası çevrimi (Her çevrim bekleme noktasından başlamaktadır)

(a. Depolama çevrimi b. Geri-alma çevrimi c. İkili çevrim)

Yukarıda anlatılan model bileşenlerinden yola çıkılarak genel süreç adımları Şekil 4'te verilmektedir. $\mathrm{Bu}$ doğrultuda, simülasyon, tanımlanan sanal varlığın (Storage_Demand) sanal lokasyona (Dummy_Location) gönderilmesi ile başlamaktadır. Hangi ürün grubunun hangi koridora gideceğini belirlemek amaciyla Tablo 4'te verilen nitelik $A t t \_S A$ ile ilişkilendirilen $S A D$ olasılık dağılımı kullanılarak, sanal varlıklar (Storage_Demand_ $i$ ) giriş lokasyonuna (Input) gönderilmektedir. Sanal varlıklar Input lokasyonuna gönderildikten sonra, $i$. koridordaki hücrelere depolanacak olan ürün gruplarının da ilgili konveyör, kuyruk ve tampon bölgelerine gönderilmesi gerekmektedir. Sanal varlıklardan ürün gruplarına geçiş de yine ürün gruplarının Input lokasyonuna, talep edilme olasılı̆̆ olan ve Tablo 4'te verilen nitelik Att_SPT ile ilişkilendirilen $S P T D_{-} i$ olasılık dağılımına göre gönderilmesiyle sağlanmaktadır. Ana giriş konveyöründe (Input_Conveyor) bulunan ürün grupları, $i$. koridora ait konveyör, kuyruk ve tampon bölgelerine gönderilmekte ve depo içi atama politikaları ile talep edilme olasılıklarının da göz önüne alınmasıyla belirlenen depolama sürelerine göre ilgili koridordaki hücrelere depolanmaktadırlar. Depolanan ürün grupları, başlangıçta "1sınma periyodu + depolama süresi" kadar; aksi halde, depolama süresi kadar bekletildikten sonra geri-alma işlemleri gerçekleştirilmektedir. Ürün grupları, giriş işleminde olduğu gibi çıkış işlemleri için de ilgili kuyruk, tampon bölge ve konveyörlere gönderildikten sonra sistemden çıkarılmaktadır.

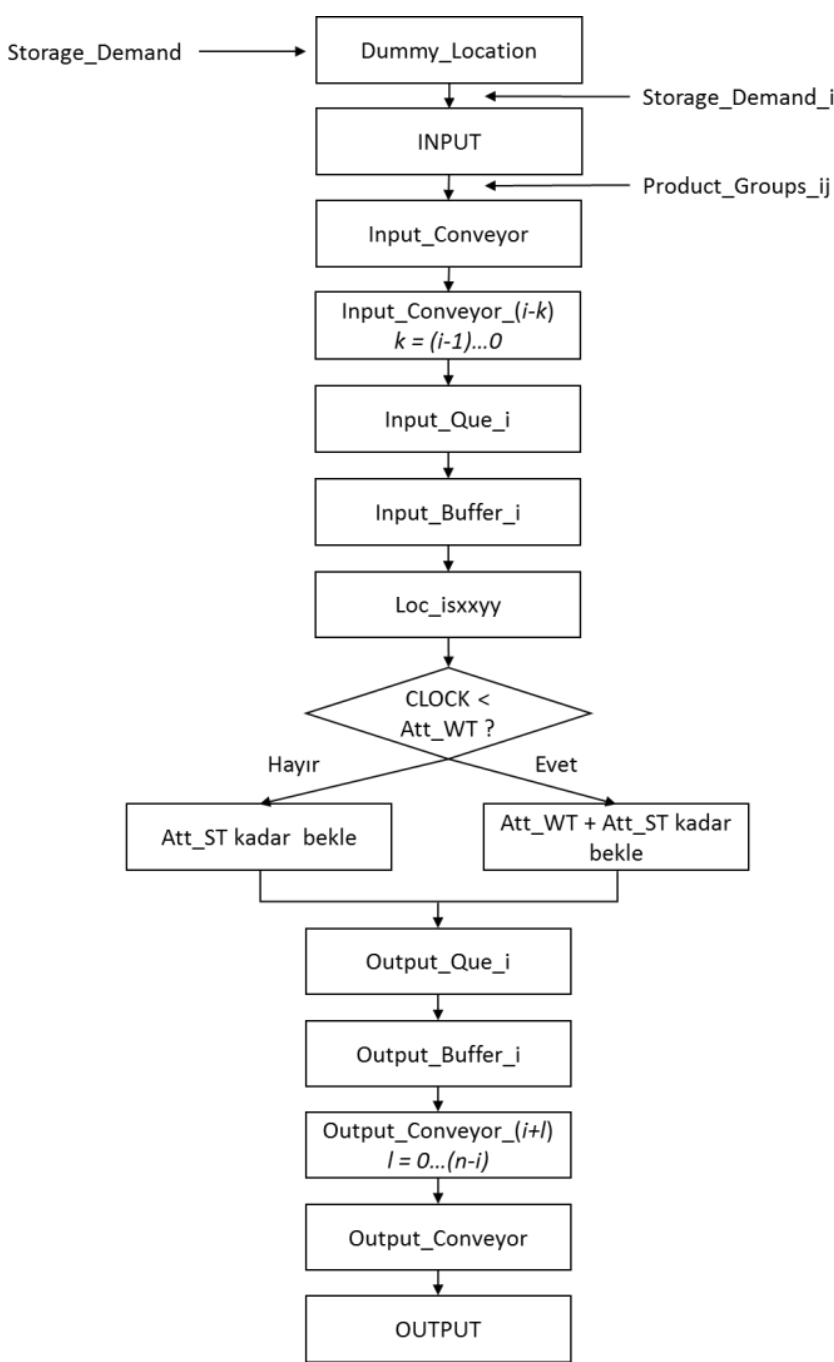

Şekil 4. Simülasyon modeli için genel süreç adımları

Yapılan çalışmada, önerilen yaklaşımın örneklendirilmesi amacıyla örnek bir depo ProModel ortamında modellenmiştir. Sistem modelinin doğru çalışıp çalışmadığını tespit edebilmek amacıyla yazılımın yeteneklerinden yararlanılmıştır. Hem sisteme giren ve çıkan ürün sayılarının tutulması ile sistemdeki mevcut ürün sayıları (work-in-process) takip edilerek hem de ProModel ortamında animasyonunun farklı hızlarda çalıştırılmasıyla, modelin doğru bir şekilde çalıştığı gözlemlenerek verifikasyonu sağlanmıştır. Buna ek olarak, yine kullanılan yazılımın özellikleri kullanılarak, varlıkların sisteme giriş ve çıkışları arasında geçen süreç takip edilmiş ve modelin doğru bir şekilde çalıştığı sonucuna ulaşılmıştır. Modelin validasyonu için ise hem model geliştiricilerin hem de uzman görüşünden yararlanarak, modelin gerçek hayatta oluşturulabilecek sistemi yeterli seviyede temsil edebilecek şekilde çalıştığ1 gözlemlenmiştir. Ayrıca, uzman görüşünden yararlanarak, geliştirilen modelin farklı koşullar altında ürettiği çıktıların, benzer bir gerçek sistemden elde edilen çıktılarla uyumlu olduğu sonucuna ulaşılmıştır. 


\section{SAYISAL ÖRNEK}

Metodoloji bölümünde detayları açıklanan yaklaşımın örneklendirilmesi amaciyla örnek bir depo ele alınmıştır. Oluşturulan örnek depoya ait bilgiler Tablo 5 'te yer almaktadir.

Bir koridor ve koridora hizmet eden bir D/GA makinesinden oluşan depoda toplamda 400 hücre (200 hücre/raf bölümü) bulunmakta olup, geri-alma politikası olarak FIFO kullanılmıştır. Ele alınan depo, rassal depo içi atama politikası altında üç farklı bekleme noktası politikası uygulanarak simüle edilmiştir. Böylelikle, hangi bekleme noktasının rassal depo içi atama politikası altında daha iyi sonuç verdiği analiz edilmeye çalışılmıştır. Bu doğrultuda, D/GA makinesi için belirlenen giriş, çıkış ve orta bekleme noktaları rassal depo içi atama politikası altında incelenmiştir. Örneğe ait depo tasarımları ise Şekil 5 ve 6'da yer almaktadır.
Tablo 5. Deponun fiziksel tasarım ve kontrol parametreleri

\begin{tabular}{lll}
\hline Parametre & \multicolumn{1}{l}{ Değer } \\
\hline Depo Boyutları & $:$ & $20 \times 10$ \\
\hline Toplam Hücre Sayısı & $:$ & 400 \\
\hline Koridor Sayısı $(i)$ & $:$ & 1 \\
\hline D/GA Makinesi Sayısı & $:$ & 1 \\
\hline $\begin{array}{l}\text { Toplam Ürün Grubu } \\
\text { Sayısı }\end{array}$ & $:$ & 8 \\
\hline $\begin{array}{l}\text { Depo İçi Atama Politikası } \\
\text { Geri-Alma Politikası }\end{array}$ & Rassal \\
\hline $\begin{array}{l}\text { D/GA Makinesi Bekleme } \\
\text { Noktası }(\forall i)\end{array}$ & $:$ & FIFO \\
\hline
\end{tabular}

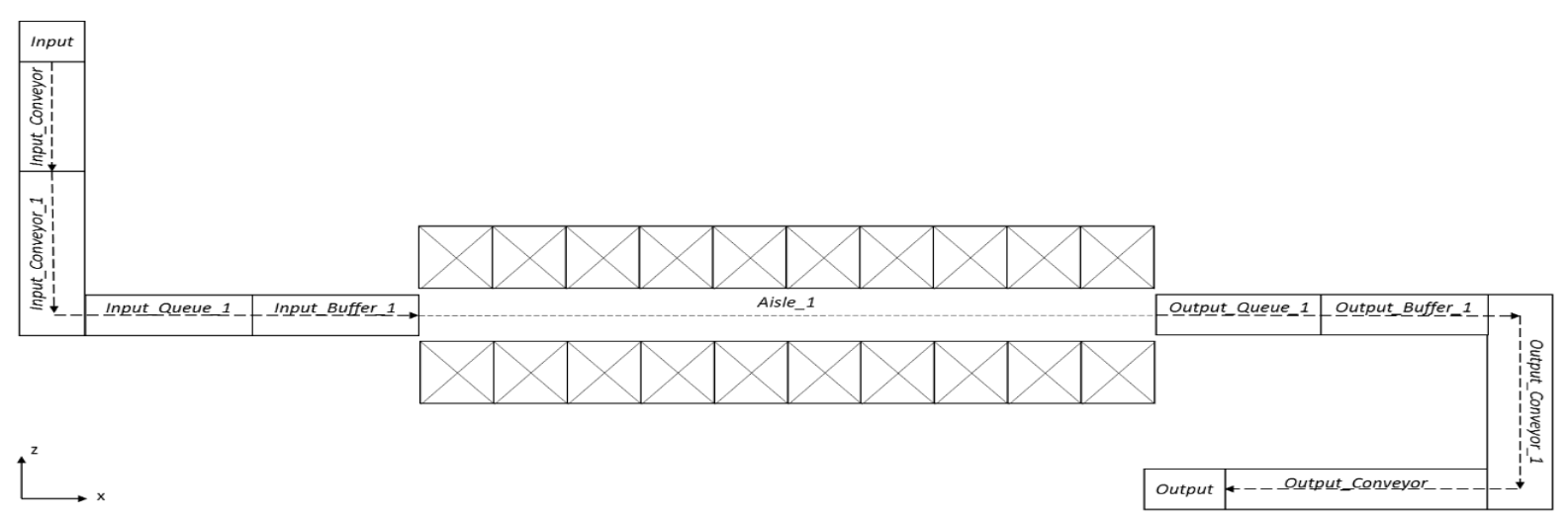

Şekil 5. Depo tasarımı (x-z eksenleri)

Tablo 5'te bazı fiziksel tasarım ve kontrol parametreleri verilen örnek depo; bir koridor $(n=1), 20 \times 10$ hücre/raf bölümü (toplam 400 hücre) ve bir D/GA makinesinden oluşmaktadır. Bununla birlikte, depoda bulunan bir koridorda toplam 8 farklı ürün grubunun $\left(m_{i}=8, i=1\right) \quad$ sistemde depoland $1 \breve{g}_{1}$ varsayılmaktadır. Çalışmanın amacı, rassal depo içi atama altında bekleme noktası politikalarının sistem üzerindeki etkisini incelemek olduğundan, ele alınan örnekte rassal depo içi atama politikasının uygulandığ ve D/GA makineleri için de farklı bekleme noktalarının olduğu varsayılmaktadır. Rassal depo içi atama politikası uygulanan ve iki raf bölümünden oluşan raflara yerleştirilen ürün gruplarının simetrik bir yerleşimi olmamakla birlikte, Şekil 7'de rafların iki bölümü de yer almaktadır. Burada dikkat edilmesi gereken unsur, rassal depo içi atama politikası dışındaki politikalar için (sınıf-tabanlı, atanmış vb.) aynı ürün gruplarının (ya da sinıfların) simetrik olarak yerleştirilebilmesi sağlamak amaciyla 2-boyutlu düzlemde dikkate alınan $x$ ve $y$ eksenlerinin yönleridir. D/GA makinesinin, karşılıklı olarak yerleştirilen ürün gruplarına (ya da sınıflara) olan uzaklığının eşit olmasını sağlamak için simülasyon modelinde oluşturulan raf yerleşiminde, $x$ ekseni değerleri her iki raf bölümü için de aynı yönde artarken, $y$ ekseni değerlerinin zıt yönlere doğru arttığı varsayılmaktadır. Böylelikle, D/GA makinesinin bulunduğu bir noktadan karşılıklı olarak yerleştirilen ürün gruplarına (ya da ürün gruplarının bulundukları hücrelere) olan uzaklık, diğer bir deyişle, ilgili ürün gruplarına ulaşma süresi eşit olmaktadır. Modellenen sistemler için varsayımlar genel olarak aşağıdaki gibi özetlenebilir:

- Toplam 400 hücreden oluşan tek koridorlu depoda 8 farklı ürün grubu bulunmaktadır.

- Depoda bir D/GA makinesi bulunmakta olup, makine bekleme noktası olarak giriş, orta ve çıkış noktaları belirlenmiştir.

- Ürünler, rassal depo içi atama politikası altında depolanmaktadır.

- Talep edilen ürünler için geri-alma politikası olarak FIFO kullanılmaktadır.

- D/GA makinesinin ve sistemin çalışmasını sağlayan diğer bileşenlerin çalışmasında bir aksama olmayacağı (arıa vb.) varsayılmaktadır.

- D/GA makinesinin bütün ürünleri aynı hızda depolayıp-geri alabildiği (tüm ürünlerin yaklaşık eşit ağırlıkta olduğu) varsayılmaktadır. 


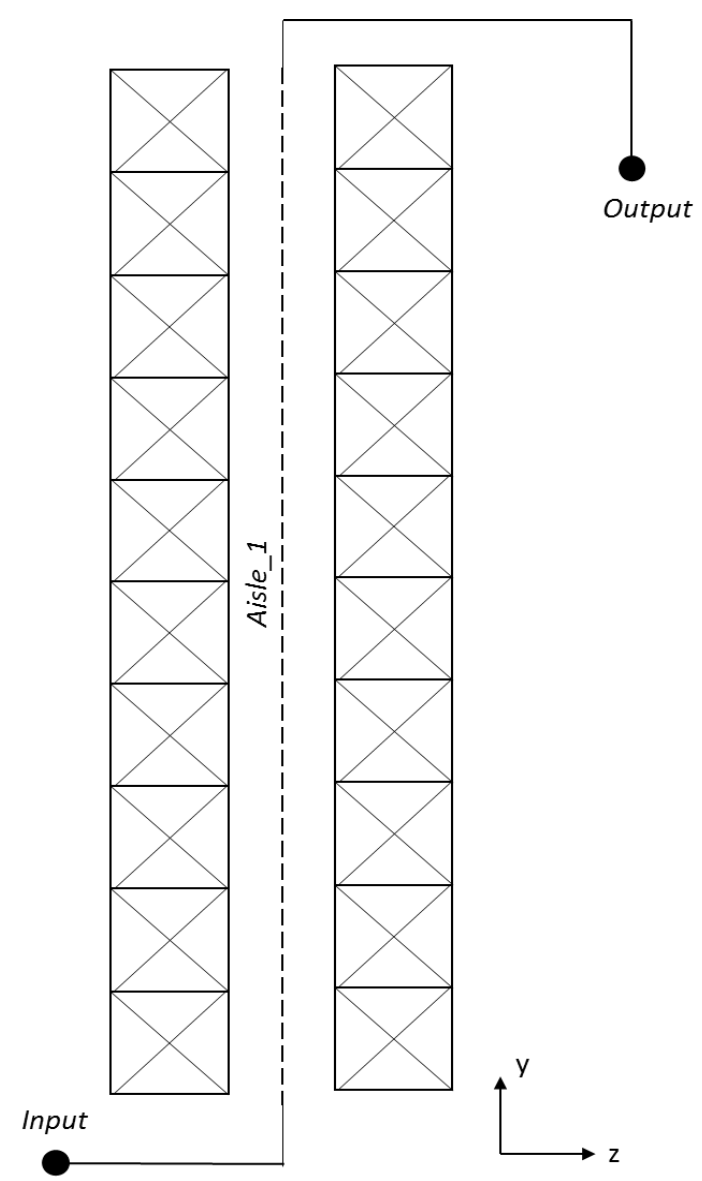

Şekil 6. Depo tasarımı (y-z eksenleri)

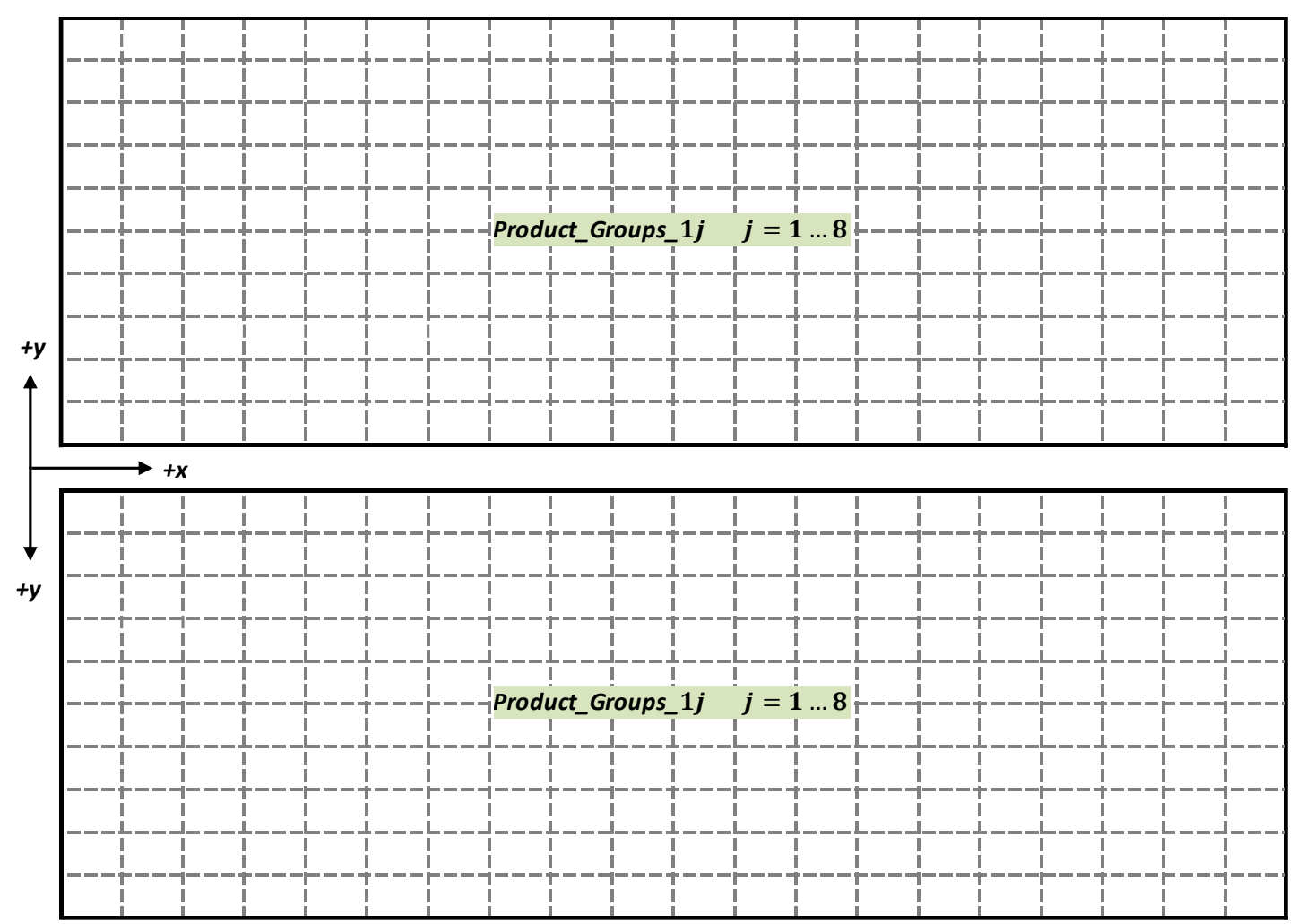

Şekil 7. Rassal depo içi atama politikası için ürün grubu-hücre atamaları 


\section{SONUÇLAR VE TARTIŞMALAR}

Önerilen yaklaşımın örneklendirilmesi amacıyla ele alınan örnekte simülasyon, sanal varlığın (Storage_Demand) sanal lokasyona (Dummy_Location) E(30) frekansiyla birer birer sınırsız sayıda gönderilmesi ile başlamaktadır. Bununla birlikte, ürün gruplarının sisteme gelme olasılıkları ile Storage_Demand_ $i$ varlıklarını ilgili koridor, konveyör ve kuyruklara gönderilme olasılıklarının, "Metodoloji" bölümünde detayları verilen ilgili nitelikler ile tutulduğu belirtilmişti. Bu doğrultuda, başlangıç durumunda Att_SA niteliği ile tutulan ve Storage_Demand_ $i$ varlıkları için kullanılan, $i$. koridora ürün gönderme olasıllğı olan $S A D$, tek bir koridor olduğu için \%100 olarak belirlenmiştir. Öte yandan, rassal depo içi atama politikası altında depolanan tüm ürün gruplarının talep edilme olasılıklarının (sisteme gönderilme olasılıklarının) eşit olduğu varsayılmıştır. Diğer bir deyişle, $i$. koridordaki hücrelere depolanmak üzere gelen sekiz (8) farklı ürün grubunun talep edilme olasılıklarını oluşturan ve $A t t \_S P T D_{-} i$ niteliği ile tutulan $S P T D_{-} i$ dağılımında, her ürün grubu için talep edilme olasıllğı $\% 12,5$ olarak belirlenmiştir.

Önerilen yaklaşımda, simülasyonun başlatılması ve ürün gruplarının ilgili hücrelere depolanmak üzere gönderilmesinden sonra geri-alma sürecine geçilmektedir. "Metodoloji” bölümünde belirtildiği gibi depo başlangıçta belirli bir oranda dolduktan sonra geri-alma işlemlerinin başlaması için ısınma periyodunun tanımlanması gerekmektedir. $\mathrm{Bu}$ doğrultuda, genel ısınma periyodu çarpanı olan Var_WT için 1000 zaman birimi (dakika) değeri belirlenmiştir. Koridordaki hücrelerin belirli bir doluluk seviyesine ulaşabilmesini sağlamak için koridor bazlı ısınma periyotları belirlenirken kullanılan $V a r_{-} W T C_{-} i j$ katsayısına ise ürün gruplarının talep edilme olasılıklarının eşit olduğu göz önüne alınarak her bir ürün grubu için beş (5) değeri verilmiştir. Diğer bir yandan, rassal depo içi atama politikası altında depolanan ürün gruplarının talep edilme olasılıkları eşit alındığından ısınma periyodunda olduğu gibi depolama süreleri de eşit kabul edilmiştir. Var_ST değişkeni ile tutulan genel depolama süresi $E$ (7200) olarak belirlenmiş olup bu süre, bir (1) katsayısı ile çarpılarak doğrudan kullanılmıştır. Bir koridor $(i=1)$, sekiz ürün grubundan oluşan örnek depo için ısınma periyodu ve depolama süresi değişken değerleri Tablo 6'da verilmektedir.

Tablo 6. Isınma periyodu ve depolama süreleri (dakika) değişkenleri

\begin{tabular}{lll}
\hline Değişken & Değer \\
\hline$V a r_{-} W T$ & $:$ & 1000 \\
\hline$V a r_{-} W T C_{-} 1 j, \forall j$ & $:$ & 5 \\
\hline$V a r_{-} W T_{-} 1 j, \forall j$ & $:$ & 5000 \\
\hline & \\
\hline Değişken & Değer \\
\hline$V a r_{-} S T$ & $:$ & $E(7200)$ \\
\hline$V a r_{-} S T C_{-} 1 j, \forall j$ & $:$ & 1 \\
\hline$V a r_{-} S T_{-} 1 j, \forall j$ & $:$ & $E(7200)$
\end{tabular}

Çalışma kapsamında önerilen simülasyon modeli, yukarıda detayları yer alan örnek bir depo için 30 replikasyon ile 1300 saat/replikasyon (çalıştırma süresi 1000, 1sınma periyodu 300 saat) çalıştırılmıştır. Burada, simülasyon çalıştııılırken kullanılan ısınma periyodu (300 saat), istatistik verilerinin alınmayacağ süreyi ifade etmektedir. Simülasyon çalışırken herhangi bir zaman diliminde elde edilen ekran görüntüsü ise Şekil 8'de yer almaktadır. Simülasyon modeli oluşturulurken 2-boyutlu depo ürün yerleşimi dikkate alındığından, şekilde yer alan simülasyon ekran görüntüsünde rafların $x$ ve $y$ eksenleri görülmektedir.

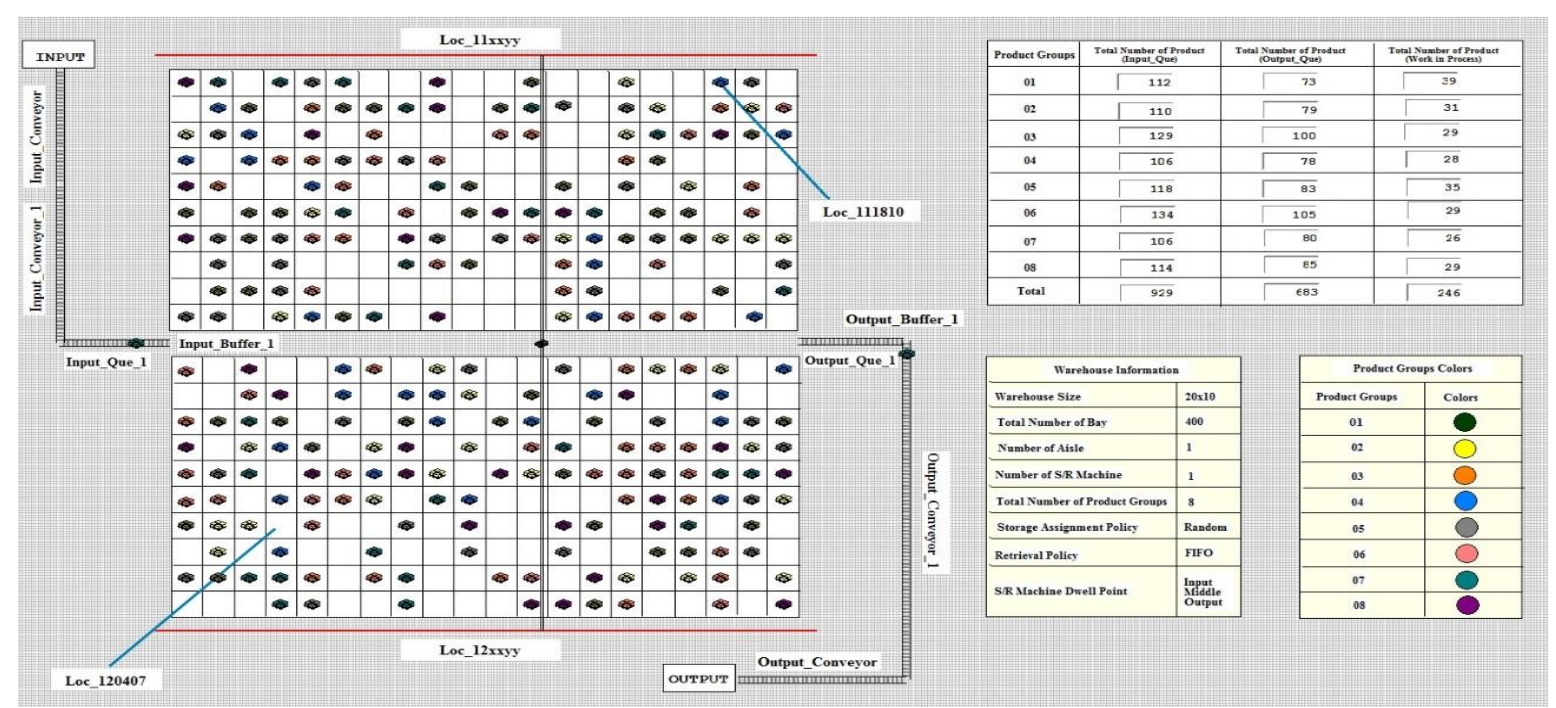

Şekil 8. Rassal depo içi atama politikası için simülasyon modeli çalışma anı ekran görüntüsü 
Çalışma kapsamında, elde edilen sonuçlar yorumlanırken sistem performansinı etkileyen parametreler dikkate alınmıştır. $\mathrm{Bu}$ doğrultuda, her bekleme noktası için ürünlerin sistemde geçirdikleri ortalama zaman (dakika), D/GA makinesinin ortalama seyahat süresi (saat) ve $\mathrm{D} / \mathrm{GA}$ makinesi kullanım oranları incelenmiştir. Elde edilen sonuçlara göre ürünlerin sistemde geçirdikleri ortalama süreler Tablo 7'de yer almaktadır. Farklı bekleme noktalarında ürünlerin sistemde geçirdikleri ortalama süreler arasında anlamlı bir farkın oluşup oluşmadığını analiz edebilmek amaciyla, 30 replikasyon sonucunda elde edilen veriler kullanılarak t-testi uygulanmıştır. Bekleme noktaları, ikili (Giriş-Orta, Giriş-Çıkış, OrtaÇıkış) olarak karşılaştırılmış olup örnek bir test sonucu Product_Groups_01 için Tablo 8'de verilmiştir. Tablo 8'de yer alan veriler doğrultusunda, $\% 5$ anlamlılık düzeyinde, farklı bekleme noktaları için ürünlerin sistemde geçirdikleri ortalama süreleri arasında anlamlı bir farklılık olmadığ 1 görülmektedir. Öte yandan, yine Product_Groups_01 için Şekil 9'a bakıldığında, belirlenen farklı bekleme noktalarında ortalama süreler için güven aralıklarının çakıştığının, dolayısıyla anlamlı bir farkın oluşmadığının grafiksel kontrolü de yapılabilmektedir. Benzer şekilde, diğer ürün grupları için de farklı bekleme noktalarında, ürünlerin sistemde geçirdikleri ortalama süreler arasında da anlamlı farkların oluşmadığı hem t-testleri sonucunda, hem de grafiksel olarak gözlemlenmiştir.

Örnek depo oluşturulurken, ürün gruplarının sisteme giriş olasılıkları (talep edilme olasılığı) eşit olarak alındığından ürünlerin sistemde geçirdikleri ortalama sürelerin de birbirine yakın olması beklenen bir durum olup, elde edilen sonuçlarda da görülmektedir. Öte yandan, bu sonuç ele alınan örnek durum için geçerli olup, gerçek hayatta tipik bir şekilde karşılaşılabilecek olan çok farklı talep dağılımları için farklı sonuçlar alınması söz konusu olabilir. Bu çalışma kapsamında geliştirilen simülasyon modeli, söz konusu farklı durumlarda kullanılabilecek esnek bir simülasyon altyapısı sağlamaya yönelik olarak sunulmuş olup, farklı talep dağılımları modele kolaylıkla girdi olarak sunularak, elde edilen sonuçlar benzer şekilde yorumlanabilir.

D/GA makinesinin kullanımdayken seyahat ettikleri süreler ile makine kullanım yüzdesi de çalışma kapsamında dikkate alınan performans parametreleri olup, Tablo 9 ve 10 'da sonuçlar sirasiyla yer almaktadır.
Tablo 7. Ürünlerin sistemde geçirdikleri ortalama süre (dakika)

\begin{tabular}{|c|c|c|c|c|}
\hline \multirow{2}{*}{$\begin{array}{c}\text { Ürün } \\
\text { Grubu }\end{array}$} & \multirow{2}{*}{ Replikasyon } & \multicolumn{3}{|c|}{ Bekleme Noktası } \\
\hline & & Giriş & Orta & Çıkış \\
\hline \multirow{6}{*}{01} & Ortalama & 6795,67 & 6919,47 & 6960,14 \\
\hline & Minimum & 6021,90 & 5996,70 & 6101,64 \\
\hline & Maksimum & 8065,29 & 7778,31 & 7765,42 \\
\hline & S. Sapma & 444,32 & 418,89 & 387,54 \\
\hline & $\begin{array}{l}\text { 95\% G.A. } \\
\text { Düsük }\end{array}$ & 6629,76 & 6763,06 & 6815,44 \\
\hline & $\begin{array}{l}\text { 95\% G.A. } \\
\text { Yüksek }\end{array}$ & 6961,58 & 7075,89 & 7104,85 \\
\hline \multirow{6}{*}{02} & Ortalama & 6953,42 & 7034,30 & 6940,60 \\
\hline & Minimum & 6282,96 & 5845,39 & 6343,35 \\
\hline & Maksimum & 8152,14 & 7821,64 & 7863,82 \\
\hline & S. Sapma & 375,39 & 447,34 & 358,66 \\
\hline & $\begin{array}{l}\text { 95\% G.A. } \\
\text { Düșük }\end{array}$ & 6813,25 & 6867,26 & 6806,68 \\
\hline & $\begin{array}{l}\text { 95\% G.A. } \\
\text { Yüksek }\end{array}$ & 7093,60 & 7201,35 & 7074,53 \\
\hline \multirow{6}{*}{03} & Ortalama & 6940,15 & 6978,69 & 6975,00 \\
\hline & Minimum & 6251,60 & 6294,24 & 6295,07 \\
\hline & Maksimum & 7884,17 & 8061,16 & 8044,89 \\
\hline & S. Sapma & 469,91 & 430,22 & 423,87 \\
\hline & $\begin{array}{l}\text { 95\% G.A. } \\
\text { Düşük }\end{array}$ & 6764,68 & 6818,04 & 6816,72 \\
\hline & $\begin{array}{l}\text { 95\% G.A. } \\
\text { Yüksek }\end{array}$ & 7115,62 & 7139,34 & 7133,27 \\
\hline \multirow{6}{*}{04} & Ortalama & 7069,23 & 6996,39 & 6934,13 \\
\hline & Minimum & 5910,63 & 5861,49 & 5882,18 \\
\hline & Maksimum & 7840,87 & 8172,07 & 7842,13 \\
\hline & S. Sapma & 430,91 & 532,26 & 444,92 \\
\hline & $\begin{array}{l}\text { 95\% G.A. } \\
\text { Düşük }\end{array}$ & 6908,33 & 6797,64 & 6767,99 \\
\hline & $\begin{array}{l}\text { 95\% G.A. } \\
\text { Yüksek }\end{array}$ & 7230,14 & 7195,14 & 7100,26 \\
\hline \multirow{6}{*}{05} & Ortalama & 6890,21 & 7093,74 & 6963,89 \\
\hline & Minimum & 6009,16 & 6367,04 & 6288,54 \\
\hline & Maksimum & 7619,30 & 7841,76 & 7580,79 \\
\hline & S. Sapma & 409,92 & 391,07 & 371,51 \\
\hline & $\begin{array}{l}\text { 95\% G.A. } \\
\text { Düşük }\end{array}$ & 6737,15 & 6947,71 & 6825,17 \\
\hline & $\begin{array}{l}\text { 95\% G.A. } \\
\text { Yüksek }\end{array}$ & 7043,28 & 7239,77 & 7102,61 \\
\hline \multirow{6}{*}{06} & Ortalama & 6994,43 & 6946,41 & 6878,50 \\
\hline & Minimum & 6189,66 & 6369,51 & 5865,03 \\
\hline & Maksimum & 7869,24 & 7869,71 & 7870,52 \\
\hline & S. Sapma & 429,94 & 399,23 & 431,85 \\
\hline & $\begin{array}{l}\text { 95\% G.A. } \\
\text { Düşük }\end{array}$ & 6833,88 & 6797,33 & 6717,25 \\
\hline & $\begin{array}{l}\text { 95\% G.A. } \\
\text { Yüksek }\end{array}$ & 7154,97 & 7095,49 & 7039,76 \\
\hline \multirow{6}{*}{07} & Ortalama & 6823,55 & 6865,30 & 6856,36 \\
\hline & Minimum & 6076,28 & 6344,19 & 6297,54 \\
\hline & Maksimum & 7411,17 & 7519,86 & 7524,71 \\
\hline & S. Sapma & 364,15 & 338,91 & 304,27 \\
\hline & $\begin{array}{l}\text { 95\% G.A. } \\
\text { Düşük }\end{array}$ & 6687,58 & 6738,75 & 6742,75 \\
\hline & $\begin{array}{l}\text { 95\% G.A. } \\
\text { Yüksek }\end{array}$ & 6959,53 & 6991,85 & 6969,98 \\
\hline \multirow{6}{*}{08} & Ortalama & 7037,86 & 6933,71 & 7057,93 \\
\hline & Minimum & 6020,39 & 5902,02 & 6139,66 \\
\hline & Maksimum & 7777,56 & 8087,14 & 8066,78 \\
\hline & S. Sapma & 417,51 & 573,25 & 454,47 \\
\hline & $\begin{array}{l}\text { 95\% G.A. } \\
\text { Düşük }\end{array}$ & 6881,96 & 6719,65 & 6888,23 \\
\hline & $\begin{array}{l}\text { 95\% G.A. } \\
\text { Yüksek }\end{array}$ & 7193,76 & 7147,76 & 7227,63 \\
\hline
\end{tabular}

S.Sapma: Standart Sapma, G.A: Güven Aralığı 
Tablo 8. Ürünlerin sistemde geçirdikleri ortalama süreler için t-testi sonucu (Product_Groups_01 için)

\begin{tabular}{|l|cc|cc|cc|}
\hline & Giriş & Orta & Giriş & Çıkış & Orta & Çıkış \\
\hline Ortalama & 6795,67 & 6919,47 & 6795,67 & 6960,14 & 6919,47 & 6960,14 \\
Varyans & 197416,70 & 175466,27 & 197416,70 & 150186,12 & 175466,27 & 150186,12 \\
Gözlem & 30,00 & 30,00 & 30,00 & 30,00 & 30,00 & 30,00 \\
Öngörülen Ortalama Fark1 & 0,00 & & 0,00 & & 0,00 & \\
df & 58,00 & & 57,00 & & 58,00 & \\
t Stat & $-1,11$ & & $-1,53$ & & $-0,39$ \\
P(T<=t) iki-uçlu & 0,27 & & 0,13 & & 0,70 \\
\hline
\end{tabular}

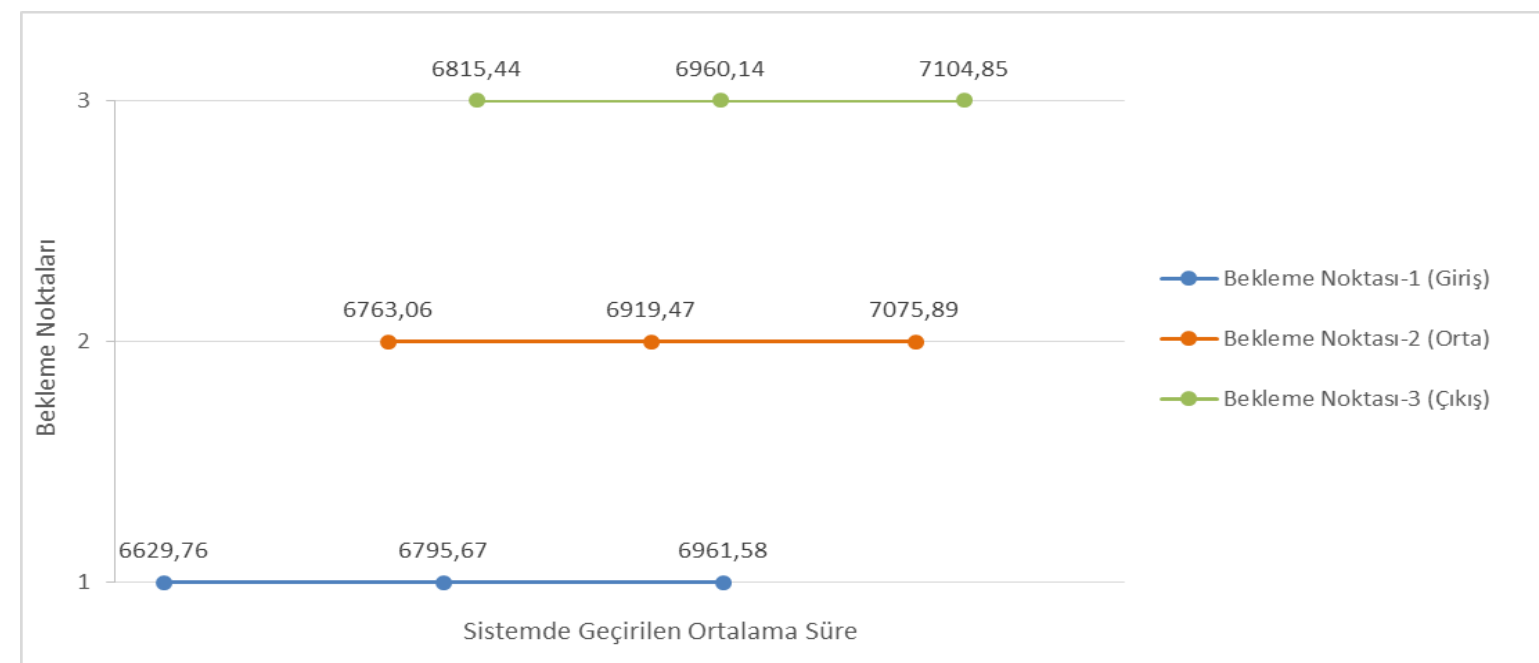

Şekil 9. Ürünlerin sistemde geçirdikleri ortalama süreler için \%95 güven aralıkları (Product_Groups_01 için)

Tablo 9. D/GA makinesinin kullanımdayken seyahat ettiği ortalama süre (saat)

\begin{tabular}{lccc}
\hline & $\begin{array}{c}\text { Bekleme Noktası } \\
(\text { Giriş })\end{array}$ & $\begin{array}{c}\text { Bekleme Noktası } \\
(\text { Orta })\end{array}$ & $\begin{array}{c}\text { Bekleme Noktası } \\
(\text { Çıkış) }\end{array}$ \\
\hline Ortalama & 0,01 & 0,01 & 0,02 \\
Minimum & 0,01 & 0,01 & 0,02 \\
Maksimum & 0,01 & 0,01 & 0,02 \\
Standart Sapma & $\sim 0$ & $\sim 0$ & $\sim 0$ \\
95\% G.A. Düşük & 0,01 & 0,01 & 0,02 \\
95\% G.A. Yüksek & 0,01 & 0,01 & 0,02 \\
\hline
\end{tabular}

Tablo 10. D/GA makinesinin kullanım yüzdesi (\%)

\begin{tabular}{lccc}
\hline & $\begin{array}{c}\text { Bekleme Noktası } \\
\text { (Giriş) }\end{array}$ & $\begin{array}{c}\text { Bekleme Noktası } \\
\text { (Orta) }\end{array}$ & $\begin{array}{c}\text { Bekleme Noktası } \\
\text { (Çıkış) }\end{array}$ \\
\hline Ortalama & 8,51 & 9,84 & 12,36 \\
Minimum & 7,88 & 9,38 & 11,80 \\
Maksimum & 8,85 & 10,23 & 12,94 \\
Standart Sapma & 0,23 & 0,20 & 0,25 \\
95\% G.A. Düşük & 8,42 & 9,76 & 12,26 \\
95\% G.A. Yüksek & 8,59 & 9,91 & 12,45 \\
\hline
\end{tabular}

Elde edilen sonuçlarda, farklı bekleme noktalarına göre makinenin seyahat ettiği ortalama sürelerin birbirlerinden çok farklı olmadığı gözlemlenmektedir. Hatta tablodaki sonuçlardan da görüldüğü gibi iki basamaklı ondalık hassasiyet seviyesinde herhangi bir farklıık oluşmadığı, yaklaşık olarak makinenin seyahat sürelerinin birbirlerine eşit olduğu görülmektedir.
Önceki durumda olduğu gibi bu sonuçların da oluşturulan örnek depo için ürün gruplarının sisteme giriş olasılıklarının (talep edilme olasılı̆̆ı) eşit olduğu ve yaklaşık olarak deponun homojen bir şekilde bu ürünlerle doldurulacak şekilde bir tasarımın oluşturulduğu örnek durum için geçerli olduğu görülmektedir. Bu nedenle, böyle bir tasarım için 
seyahat sürelerinin yaklaşık olarak eşit olması beklenen bir sonuç olmakla birlikte, gerçek hayatta ortaya çıkabilecek olan farklı durumlarda seyahat sürelerinin farklılaşması söz konusu olabilir. Geliştirilen simülasyon modeli ile söz konusu farklı durumların kolay bir şekilde modele girdi olarak sunulabilmesi mümkün olmaktadır.

Diğer bir yandan, makine kullanım yüzdelerinde anlamlı farkların oluştuğu Tablo 10'da görülmekle birlikte, istatistiksel olarak anlamlılığını göstermek için t-testi uygulanmış olup test sonuçları Tablo 11'de, güven aralıklarını gösteren grafiksel sonuçlar ise Şekil 10 'da yer almaktadır. Belirlenen farklı bekleme noktaları için D/GA makinesi kullanım yüzdeleri sonuçlarının yer aldığ düzeyinde, farklı bekleme noktaları için D/GA makinesi kullanım yüzdeleri arasında anlamlı farklılıklar olduğu görülmektedir. Benzer şekilde, Şekil 10’da, \%95 güven aralığ 1 için söz konusu anlamlı farklılıkların oluştuğu gözlenmektedir. Bu durumda, farklı bekleme noktaları ile çalıştırılan simülasyon modelinde, sisteme giren ve çıkan ürün sayılarının da yaklaşık olarak eşit olduğu tutulan değişkenler ile bilinmekte olduğundan, makine kullanım yüzdesi düşük olan bekleme noktasının daha iyi performansa sahip olduğu söylenebilir. Elde edilen sonuçlara göre de makine bekleme noktası giriş konumundayken kullanım yüzdesinin daha düşük olduğu görülmektedir.

Tablo 11. D/GA makinesinin kullanım yüzdesi için t-testi sonucu

\begin{tabular}{|l|cc|cc|cc|}
\hline & Giriş & Orta & Giriş & Çıkış & Orta & Çıkış \\
\hline Ortalama & 8,51 & 9,84 & 8,51 & 12,36 & 9,84 & 12,36 \\
Varyans & 0,05 & 0,04 & 0,05 & 0,06 & 0,04 & 0,06 \\
Gözlem & 30,00 & 30,00 & 30,00 & 30,00 & 30,00 & 30,00 \\
Öngörülen Ortalama Fark1 & 0,00 & & 0,00 & & 0,00 & \\
df & 57,00 & & 58,00 & & 56,00 \\
t Stat & $-23,77$ & & $-62,03$ & & $-42,69$ \\
P(T<=t) & 0,00 & & 0,00 & & 0,00 \\
\hline
\end{tabular}

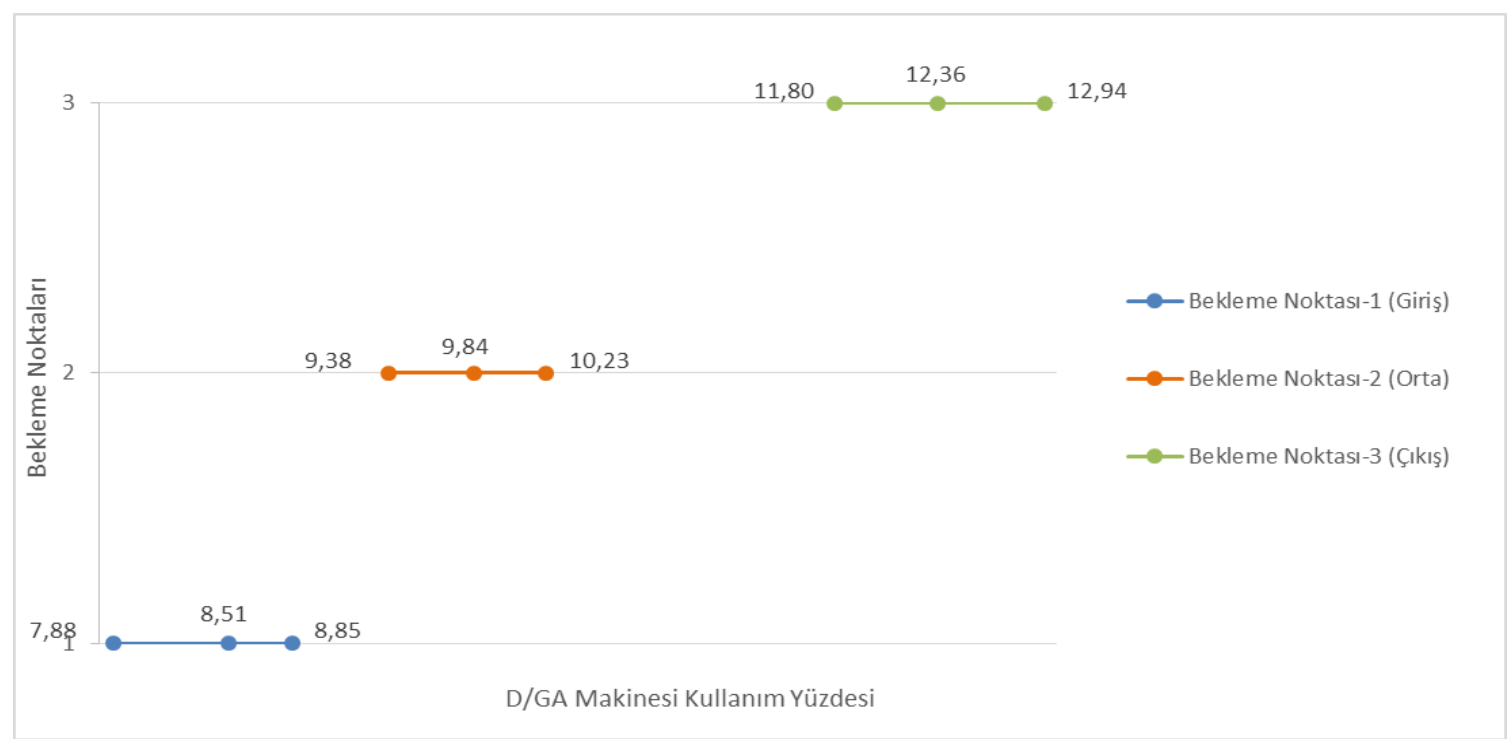

Şekil 10. D/GA makinesi kullanım yüzdesi için \%95 güven aralıkları

\section{SONUÇLAR}

Hem üretim hem dağıtım ortamlarında, ürünlerin depolanması ve geri-alınması için kullanılan OD/GA sistemleri, malzemeleri belirli bir otomasyon derecesinde hassas, doğru ve hızlı bir şekilde işleyen, depolayan ve geri-alan ekipman ve kontrollerin bileşimi olarak tanımlanabilir. OD/GA sistemleri, ürünlerin depolanması ve geri-alınması için verimli çalışacak ve hızlı tepki verecek şekilde tasarlanmalıdır. Ancak, OD/GA sistemini kullanacak olan müşterilerden gelen istek ve kısıtların, fiziksel tasarım ve kontrol parametrelerinin belirlenmesinde rol oynamasının yanında, sistem ile ilgili belirsizliklerin de olması OD/GA sistemi tasarımını karmaşık bir hale getirmektedir. Tüm bu unsurlar dikkate alındığında, OD/GA sistemi tasarımı karmaşık bir optimizasyon problemi olarak karşımıza çıkmaktadır. Problem genel olarak daha dar kapsamda ele alındığında, bu tür bir optimizasyon probleminin çözümü için analitik modellerin kullanıldığı görülmektedir. Ancak, problem karmaşıklığı arttığında, en uygun çözümü geleneksel yöntemler ve deneyimlerle bulmak zorlaştığı gibi böyle bir problemi çözme süreci de uzun zaman almaktadır. Dolayısıyla, analitik modellerin yanında, karmaşık 
problemlerin çözümü için sıklıkla simülasyon modellerinin de kullanıldığı görülmektedir.

$\mathrm{Bu}$ çalışmada, genel olarak OD/GA sistemlerinin simülasyon ile modellenmesi üzerinde durulmuştur. Çalışmada, OD/GA sistemlerinin simülasyon ile modellenmesi için bir altyapı oluşturulmaya çalışılmış ve bu amaçla bir yaklaşım önerilmiştir. Önerilen yaklaşımın örneklendirilmesi amacıyla bir koridor, bir D/GA makinesi ve ayrı giriş ve çıkış noktalarından oluşan bir depo oluşturulmuştur. Depoda, sekiz farklı ürün grubunun, eşit talep edilme olasılıkları dikkate alınarak depoya geldiği ve rassal depo içi atama politikası altında depolandığı varsayılmıştır. Senaryo parametresi olarak D/GA makinesi için üç farklı bekleme noktası (giriş, orta ve çıkış) belirlenmiştir. Böylece, farklı bekleme noktalarının sistem performansı üzerindeki etkisinin analiz edilmesi amaçlanmıştır. Elde edilen sonuçlar ürünlerin sistemde geçirdikleri ortalama zaman, D/GA makinesinin ortalama seyahat süresi ve D/GA makinesi kullanım yüzdesi olarak belirlenen sistem performansı açısından incelenmiştir. Ele alınan örnekte, ürünlerin sistemde geçirdiği ortalama zaman ile D/GA makinesinin ortalama seyahat süresi açısından anlamlı farklılıkların oluşmadığı gözlemlenmiştir. Öte yandan, ele alınan örnek için D/GA makinesi bekleme noktası giriş konumundayken makine kullanım yüzdesinin daha düşük olduğu, dolayısıyla söz konusu konumlandırmanın daha iyi bir performansa sahip olduğu görülmektedir. Gelecek çalışmalarda, geliştirilen simülasyon modelinin altyapısı kullanılarak farklı stratejilerin dikkate alınması ve bunların kapsamlı bir şekilde analiz edilmesi amaçlanmaktadır.

\section{KAYNAKLAR}

[1] Roodbergen, K. J., \& Vis, I. F. (2009). A Survey of Literature on Automated Storage and Retrieval Systems. European Journal of Operational Research, 194(2), 343-362.

[2] Ghomri, L., \& Sari, Z. (2015). Mathematical Modeling of Retrieval Travel Time for Flow-Rack Automated Storage and Retrieval Systems. IFACPapersOnLine, 48(3), 1906-1911.

[3] Park, B. C. (2001). An Optimal Dwell Point Policy for Automated Storage/Retrieval Systems with Uniformly Distributed, Rectangular Racks. International Journal of Production Research, 39(7), 1469-1480.

[4] Regattieri, A., Santarelli, G., Manzini, R., \& Pareschi, A. (2013). The Impact of Dwell Point Policy in an Automated Storage/Retrieval System. International Journal of Production Research, 51(14), 4336-4348.

[5] Bortolini, M., Accorsi, R., Gamberi, M., Manzini, R., \& Regattieri, A. (2015). Optimal Design of AS/RS Storage Systems with Three-Class-Based Assignment Strategy under Single and Dual Command Operations. The International Journal of Advanced Manufacturing Technology, 79(912), 1747-1759.

[6] Gagliardi, J. P., Renaud, J., \& Ruiz, A. (2012a). Models for Automated Storage and Retrieval Systems: A Literature Review. International Journal of Production Research, 50(24), 71107125.

[7] Vasili, M. R., Tang, S. H., \& Vasili, M. (2012). Automated Storage and Retrieval Systems: A Review on Travel Time Models and Control Policies. Warehousing in the Global Supply Chain, 159-209.

[8] Potrc, I., Lerher, T., Kramberger, J., \& Sraml, M. (2004). Simulation Model of Multi-Shuttle Automated Storage and Retrieval Systems. Journal of Materials Processing Technology, 157, 236-244.

[9] Eldemir, F., Graves, R. J., \& Malmborg, C. J. (2003). A Comparison of Alternative Conceptualizing Tools for Automated Storage and Retrieval Systems. International Journal of Production Research, 41(18), 4517-4539.

[10]Lerher, T., Sraml, M., Kramberger, J., Potrc, I., Borovinsek, M., \& Zmazek, B. (2006). Analytical Travel Time Models for Multi Aisle Automated Storage and Retrieval Systems. The International Journal of Advanced Manufacturing Technology, 30(3-4), 340-356.

[11] Guo, S. M., \& Liu, T. P. (2008). Simulation Evaluation of Single Shuttle and Twin Shuttle AS/RS. IJEBM, 6(2), 106-115.

[12] Yan, B., \& Lee, D. (2009). AS/RS Simulation and Optimization Based on Flexsim. Intelligent Systems and Applications, International Workshop, 23-24 Mayıs, Wuhan, China.

[13]Lerher, T., Sraml, M., Potrc, I., \& Tollazzi, T. (2010). Travel Time Models for Double-Deep Automated Storage and Retrieval Systems. International Journal of Production Research, 48(11), 3151-3172.

[14] Tang, X. Y., Yang, L. L., Zhang, J. J., Shi, J., \& Chen, L. C. (2013). Research on AS/RS Simulation Based on Flexsim. Applied Mechanics and Materials, 347, 406-410.

[15] Gagliardi, J. P., Renaud, J., \& Ruiz, A. (2014). A Simulation Modeling Framework for MultipleAisle Automated Storage and Retrieval Systems. Journal of Intelligent Manufacturing, 25(1), 193207.

[16] Bahrami, B., Aghezzaf, E. H., \& Limere, V. (2014). Simulation Based Performance Analysis of an End-Of-Aisle Automated Storage and Retrieval System. 3rd International Conference on Operations Research and Enterprise Systems (ICORES 2014), 334-341.

[17]Fan, W., Dongfen, G., Shujuan, T., Hong, H., \& Xiao, C. (2015). Travel Time Model Of The Storage/Retrieval Machine For Multi-Deep AS/RS Based On Flexsim. Open Cybernetics \& Systemics Journal, 9, 1833-1839. 
[18] Van Den Berg, J. P., \& Gademann, A. J. R. M. (2000). Simulation Study of an Automated Storage/Retrieval System. International Journal of Production Research, 38(6), 1339-1356.

[19] Meller, R. D., \& Mungwattana, A. (2005). AS/RS Dwell-Point Strategy Selection at High System Utilization: A Simulation Study to Investigate the Magnitude of the Benefit. International Journal of Production Research, 43(24), 5217-5227.

[20] Manzini, R., Gamberi, M., \& Regattieri, A. (2006). Design and Control of an AS/RS. The International Journal of Advanced Manufacturing Technology, 28(7-8), 766-774.

[21]Zhou, G., \& Mao, L. (2010). Design and Simulation of Storage Location Optimization Module in AS/RS Based on FLEXSIM. International Journal of Intelligent Systems and Applications, 2(2), 33.
[22] Gagliardi, J. P., Renaud, J., \& Ruiz, A. (2012b). On Storage Assignment Policies for Unit-Load Automated Storage and Retrieval Systems. International Journal of Production Research, 50(3), 879-892.

[23] Meneghetti, A., \& Monti, L. (2013). Sustainable Storage Assignment and Dwell-Point Policies for Automated Storage and Retrieval Systems. Production Planning \& Control, 24(6), 511-520.

[24] Schenone, M., Mangano, G., \& Grimaldi, S. (2016). A Simulation Approach for Computing Travel Times of Warehousing Systems: Application for AS/RS in a Class-Based Storage Configuration. International Journal of Innovations in Engineering and Technology, 7(4), 79-94. 